\title{
DNA Damage-Inducible Transcript 4 Protein
}

National Cancer Institute

\section{Source}

National Cancer Institute. DNA Damage-Inducible Transcript 4 Protein. NCI Thesaurus.

Code $C 104186$.

DNA damage-inducible transcript 4 protein (232 aa, $\sim 25 \mathrm{kDa}$ ) is encoded by the human DDIT 4 gene. This protein is involved in responses to cellular stress and regulates apoptosis in response to DNA damage. 